\title{
INTEROPERABILITY AND STANDARDISATION IN THE DEPARTMENT OF DEFENCE: AN EXPLORATORY STUDY
}

\author{
J. de Waal ${ }^{1}$ and A.J. Buys ${ }^{2}$ \\ Department of Engineering and Technology Management \\ University of Pretoria, South Africa \\ 1.johanndewaal@lantic.net, ${ }^{2}$ andre.buys@up.ac.za
}

\begin{abstract}
The political changes in South Africa have extended its international obligations by actively involving it in the social wellbeing of troubled African states. Under the auspices of the United Nations, this role is manifested in peacekeeping operations and other standard international practices. The ability of African allied forces to train, exercise, and operate efficiently, effectively, and economically together depends on the interoperability of their operational procedures, doctrine, administration, materiel and technology. This implies that all parties must have the same interpretation of 'interoperability'. In this study, a conceptual model that explains interoperability and standardisation in terms of a systems hierarchy and the systems engineering process is developed. The study also explores the level of understanding of interoperability in the South African Department of Defence in terms of the levels of standardisation and its relationship to the concepts of systems, systems hierarchy, and systems engineering.
\end{abstract}

\section{OPSOMMING}

Die politieke veranderinge in Suid-Afrika het daartoe aanleiding gegee dat verdere internasionale verpligtinge die land opgelê is. Suid-Afrika, in samewerking met mede-Afrika lande en onder toesig van die Verenigde Nasies, moet deur middel van vredesoperasies by onstabiele Afrika lande betrokke raak. Die vermoë om gesamentlik aan vredesopleiding, vredesoefeninge en vredesoperasies op ' $n$ effektiewe, doeltreffende en ekonomiese wyse deel te neem, vereis dat daar versoenbaarheid tussen onderlinge operasionele prosedures, doktrine, administrasie, materieel en tegnologie is. Dit beteken dat alle partye eens omtrent die begrip 'versoenbaarheid' moet wees. In hierdie studie is ' $n$ konseptuele model wat versoenbaarheid en standaardisasie verduidelik in terme van die stelselhiërargie en die stelselingenieursweseproses ontwikkel. Hierdie studie het ook die vlak van begrip en verstaan van versoenbaarheid in die Suid-Afrikaanse Departement van Verdediging in terme van die vlakke van standaardisasie en die verhouding tot die konsepte van stelsels, stelselhiërargie en stelselingenieurswese ondersoek.

1 This author was enrolled for the MEng (Engineering Management) at the Department of Engineering and Technology Management, University of Pretoria. 


\section{INTRODUCTION}

South Africa's regional conflict-resolution and peace-building efforts commit the South African National Defence Force (SANDF), in alliance with other regional forces, to peacekeeping operations. These include military diplomacy and participation in international and regional defence structures such as the Inter-State Defence and Security Committee (ISDSC) and the Southern African Development Community (SADC) [1]. It is therefore crucial that capability development should enhance interoperability between the SANDF and other forces in the sub-region, in order to ensure effective multinational operations.

The government's initiatives regarding co-operation with other forces, access to global markets, and the international trend to buy rather than develop equipment, encourage armament project managers to think more in terms of interoperability. But do the military planners and project managers really understand the concept of interoperability and its implications? Do they know about standardisation as an integral part of all the systems in the Department of Defence (DOD)? Are they familiar with systems and systems hierarchies? At what level of management does the DOD perceive the initiation of standardisation? What methods of knowledge transfer are available to top management to learn about standardisation?

This research project attempts to determine and explore the DOD's knowledge and application level regarding standardisation by finding answers to the questions raised above. It also attempts to ascertain which related concepts can be used in a model to promote the understanding and application of standardisation in the military context, by linking current standardisation theories and applications with other system elements.

\section{INTEROPERABILITY AND STANDARDISATION}

The imposition by the Union of Soviet Socialist Republics (USSR) of undemocratic forms of government, and the repression of effective opposition and of basic human and civic rights and freedoms in many Central and Eastern European countries - as well as elsewhere in the world - led to the signing of the Brussels Treaty in March 1948. This marked the determination of Western European countries to develop a common defence system and to strengthen the ties between them [2]. Negotiations with the United States and Canada led to the creation of a single North Atlantic Alliance based on security guarantees and mutual commitments. The North Atlantic Treaty of April 1949 was established within the framework of Article 51 of the United Nations Charter.

The North Atlantic Treaty Organisation (NATO) provides the forums in which its members consult on any issues they may choose to raise, and take decisions on political and military matters affecting their security. It provides the structures needed to facilitate consultation and co-operation between them in political, military, economic, scientific and other fields [2].

One of the key structures that emerged was the NATO Standardisation Organisation 
(NSO). The NSO's current role is to enhance interoperability, contributing to the ability of Alliance forces to train, exercise, and operate effectively together - and, when appropriate, in the execution of their assigned tasks with forces of partner and/or other nations. It does this by initiating, harmonising, and co-ordinating standardisation efforts throughout the Alliance, and providing support for standardisation activities [2].

In 1999, NATO’s Heads of State and Governments launched a Defence Capabilities Initiative, with the aim of improving NATO defence capabilities in future multinational operations. A special focus was placed on improving interoperability among Alliance forces, and where appropriate between Alliance and partner/other forces [3].

The following aims of NATO, taken from Chapter 17 of NATO's Handbook [2], should be just as relevant for the African Union (AU) and SADC:

- $\quad$ NATO policy is to encourage nations to develop, agree and implement common concepts, doctrines, procedures, criteria and designs to enhance operational effectiveness, and improve efficiency in the use of available military resources.

- Major changes in NATO involving new and more delicate missions, Partnership for Peace (PfP), and enlargement, will necessitate clearly defined standardisation parameters and require an appropriate level of standardisation to allow collaborative operations, training, and exercises. In particular, the identification and implementation of interoperability objectives for PfP-nations will become increasingly important - as will involvement and integration in the standardisation process.

- Through NATO standardisation, Alliance nations will enhance their capability to perform the whole range of Alliance tasks and missions. NATO standardisation also adds political value as an outward demonstration of cooperation and solidarity.

It would be wise to learn from NATO's fifty years of experience of forces working together when designing the African Standby Force Brigades. The idea is not to copy NATO but to use NATO's established knowledge base as a point of departure when developing Africa's own systems. In this context, NATO's definition of interoperability and standardisation is used as the starting point to establish a South African understanding of the concepts.

In accordance with Alliance policy, national and NATO authorities are encouraged to develop, agree, and implement concepts, doctrines, procedures, and designs which will enable them to achieve and maintain interoperability. This requires that the necessary levels of compatibility, interchangeability, or commonality in operational procedural, materiel, technical and administrative fields be established [2].

The definitions of 'compatibility', 'interchangeability' and 'commonality' used by the International Organization for Standardization (ISO) and the United Kingdom Ministry of Defence are as follows [3]: 
- Compatibility (lowest level of standardisation): The suitability of products, processes or services for use together under specific conditions to fulfil relevant requirements without causing unacceptable interactions. (Units shall function together within an operational environment.)

- Interchangeability: The suitability of products, processes or services to be used in place of another to fulfil the same requirement. (Units can be swapped within an operational environment.)

- Commonality (highest level of standardisation): Utilization of the same doctrine, procedures or equipment. (Units are identical within an operational environment.)

NATO's definition of standardisation reads: “The development and implementation of concepts, doctrines, procedures and designs in order to achieve and maintain the compatibility, interchangeability or commonality which is necessary to attain the required level of interoperability, or to optimise the use of resources, in the fields of operations, materiel and administration” [4]. According to NATO's understanding of interoperability and standardisation, these concepts are interrelated and inseparable. The intensity of interoperability can thus be defined in terms of the levels of standardisation.

The broad goals of standardisation as determined by the UK Ministry of Defence (MOD) [5] are summarised as follows:

- Promote improvement in the quality of products (goods), processes, and services by defining those features and characteristics that govern their ability to satisfy given needs - i.e. their fitness for the purpose.

- Promote improvement in the quality of life - i.e. safety, health, and protection of the environment.

- Promote economies in manufacture through the economic use of materials, energy, and human resources in the production and exchange of goods - i.e. the efficient use of resources.

- Facilitate collaboration and promote conditions for trade by the removal of barriers caused by differences in national practices, thus enabling international competition.

- Provide a recognised yardstick against which products, processes, or service performance can be assessed.

- Set out unambiguous technical requirements in a form suitable for reference or quotation for contractual purposes.

Reflecting on these goals, it is clear that these could be the goals of any standardisation program in industry, not just in government and its respective departments (such as the military). 
Michael Codner [6] confirmed that interoperability could be further analysed by reference to the actors and parties involved. He explained: "There are organisational, behavioural, logistic and technical aspects to joint interoperability. A shift towards joint command and force structures is organisational. The adoption of a common doctrinal hierarchy is behavioural.” The integration of logistics into a single national logistics command, and the integration of single service command systems into single joint strategic, operational, and tactical command systems, would be examples of logistic and technical interoperability [6].

Behavioural interoperability is defined as that dimension of interoperability which is governed by human responses, in the form of behaviour patterns (actions) by individuals and groups, to their perceptions of the security environment [6]. Military behavioural interoperability specifically may be described with reference to institutional prescriptions and guidance in the form of security and defence policies, military strategy and doctrine, and the wider social descriptions and modifiers of behaviour such as a national constitution, legal system, customs, culture, and religion [6]. This extends the fields mentioned in the definition of interoperability.

The definitions and discussions pertaining to interoperability and standardisation call attention to the importance of the interface between elements at different levels to create congruity. The principle of 'interface between elements' is very closely related to systems, which are embedded in systems hierarchies. These interfaces must be managed through the respective systems' life-cycles that give rise to considering the principles of systems engineering, which in turn encompass practices such as configuration-, standardisation-, project-, and quality-management. The question arises: can the research questions be answered by indicating the relationships between interoperability and standardisation on the one hand, and the system-related concepts mentioned earlier on the other? This requires a broad review of these concepts to see how they relate to standardisation and interoperability.

\section{SYSTEMS HIERARCHY, LIFE-CYCLES, SYSTEMS ENGINEERING, AND STANDARDISATION}

A very acceptable definition is owed to the late Austrian biologist Ludwig von Bertalanffy, as quoted by Bellinger [7]: “A system is an entity that maintains its existence through the mutual interaction of its parts".

Bellinger also states that open systems are organic and must interact with their environment in order to maintain their existence. All systems are subsystems of larger systems, and are at the same time composed of subsystems [7]. It stands to reason that interaction can only happen if there is a certain level of interoperability and standardisation between the parts.

Hodge and Walpole [8] (from the Australian Department of Defence) adapted the general systems hierarchy of economist Kenneth Boulding, one of the founders of The Society for General Systems Theory, to a range of defence systems and "systems of systems", using the systems' capacity to handle data information and knowledge as the key discriminator. 
The current systems hierarchy used by the SANDF, levels L1 to L8, is depicted along with the hierarchies of Boulding in Figure 3. It is compiled to demonstrate the relationship between the two defence perspectives: the SANDF's alongside the original hierarchy of Boulding.

Military systems are known for their long life-cycles and complex compositions. The life-cycle is in turn synonymous with systems and the systems hierarchy, as Boulding [9] said: "There is hardly a science in which the growth phenomenon does not have importance, and though there is a great difference in complexity between the growth of crystal, embryos, and societies, many of the principles and concepts which are important at lower levels are also illuminating at higher levels."

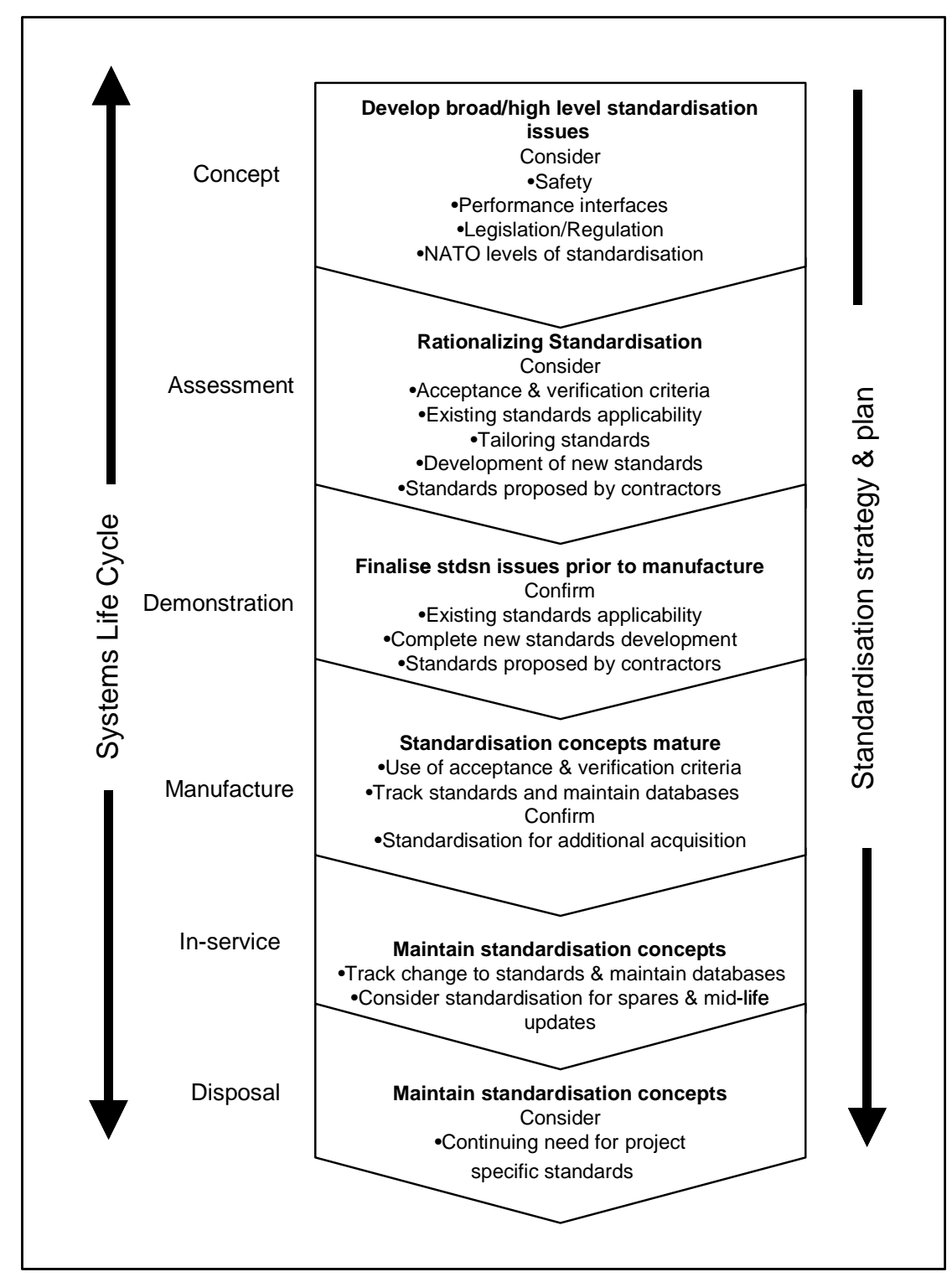

Figure 1: Standardisation activities during the system's life-cycle 
There are definite standardisation actions during the life-cycle of a system, as reflected in Figure 1 [10]. The indicated interface and existence of standardisation throughout the life-cycle justifies its presence and linking it with systems. It can be deduced from this model that standardisation is a process that must be executed and managed - and that an interdisciplinary engineering management process is required. This management process is captured in the concept of systems engineering.

The USA Department of Defense considers a logical sequence of activities and decisions that transforms an operational requirement into a description of system performance parameters (standards) and preferred system configuration (interoperability) as generally accepted principles of systems engineering. The systems engineering process is a top-down, comprehensive, iterative, and recursive problem-solving process, applied sequentially through all the life-cycle stages of a system. Within the systems hierarchy framework the systems engineering process is applied sequentially, one level at a time, adding additional detail and definition with each level of development [11].

The performance parameters (standards) and systems configuration (interoperability), and the top-down process through all the life-cycle stages, justify the use of systems engineering as part of the concept to explain standardisation and interoperability.

\section{CONCEPTUAL MODEL}

From the above discussions, it is clear that a conceptual model is required that links all the concepts we have mentioned. A model that explains interoperability and standardisation in terms of these concepts is proposed.

The systems hierarchy used by the South African DOD, as shown in Figure 2, does not address Level 9 (Transcendental) as designed by Boulding. If the DOD wishes to consider the strategic visions of the Government in relation to the AU, the African Standby Force (ASF), and the Developmental Peacekeeping initiatives, it will have to extend the hierarchy. To achieve this, two additional levels are added to the systems hierarchy, as shown in Figure 2.

The advantage of viewing the extended systems hierarchy more holistically lies in the fact that the DOD should no longer do anything strategic in isolation. It can also see its interfaces with other external organisations. From a standardisation point of view, it has to consider the other parties when joint operational, administrative, and procedural processes are developed.

Michael Codner [6] said that the higher the likelihood of combat during an operation and the more intense the level of fighting, the greater the requirement for a high degree of interoperability. This sparked the idea of aligning these concepts with the systems hierarchy, as depicted in Figure 3. The links to the NATO definitions are as follows: 
- $\quad$ Levels 9 \& 10: Interoperability

- Levels 7 \& 8: Compatibility (lowest level of standardisation)

- Level 6: Interchangeability (medium level of standardisation)

- Levels 1-5: Commonality (highest level of standardisation)

\begin{tabular}{|c|c|c|c|c|c|}
\hline \multirow{4}{*}{\multicolumn{2}{|c|}{ 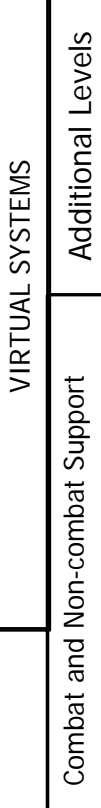 }} & L10 & $\begin{array}{l}\text { Government } \\
\text { Multi-Department } \\
\text { System }\end{array}$ & $\begin{array}{l}\text { Department of Defense } \\
\text { Other Government Departments }\end{array}$ & $\begin{array}{l}\text { Transcendental } \\
\text { Systems of unknowns and } \\
\text { unknownables }\end{array}$ \\
\hline & & L8 & $\begin{array}{l}\text { Joint Higher } \\
\text { Order Military } \\
\text { System }\end{array}$ & $\begin{array}{l}\text { Defence Headquarters } \\
\text { Army, Air Force, } \\
\text { Navy, Medical Service }\end{array}$ & $\begin{array}{l}\text { Social- Systems built upon collective } \\
\text { shared identification with roles and } \\
\text { symbols, set of roles tied together with } \\
\text { Communication, displaying interpersonal } \\
\text { Accommodation. The unit for considering } \\
\text { Social systems is the "role" not person. }\end{array}$ \\
\hline & & L7 & $\begin{array}{l}\text { Operational } \\
\text { System } \\
\text { (Ops Capability) }\end{array}$ & $\begin{array}{l}\text { Battlegroup consisting of } \\
\text { Elements of different Army } \\
\text { Corps', eg Infantry, Artillery, } \\
\text { Engineers supported by } \\
\text { helicopters }\end{array}$ & $\begin{array}{l}\text { Human Systems that display self } \\
\text { consciousness (knows that it knows), } \\
\text { system behaviour based on more comple } \\
\text { images with abstract dimensions. } \\
\text { The systems' unit is the person }\end{array}$ \\
\hline & & L6 & $\begin{array}{l}\text { Core System } \\
\text { (Core Capability) }\end{array}$ & $\begin{array}{l}\text { Mechanized Infantry (trained } \\
\text { Troops with theirl CV's, the } \\
\text { maintenance element, support } \\
\text { element, etc.) }\end{array}$ & $\begin{array}{l}\text { Animal- Systemsdisplaying } \\
\text { self-awareness, neurological control, } \\
\text { teleological system behaviour is based on } \\
\text { image of environment as a whole (more } \\
\text { than the sum of the parts. }\end{array}$ \\
\hline & \multirow{5}{*}{ 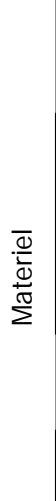 } & L5 & $\begin{array}{l}\text { Products } \\
\text { System } \\
\text { (Pseudo Capability) }\end{array}$ & $\begin{array}{l}\text { G5-canon, G5 Ammo, } \\
\text { G5 Gun-tractor, etc }\end{array}$ & $\begin{array}{l}\text { Plant-Systems of differentiated } \\
\text { and mutual dependent parts with blue } \\
\text { print growth. }\end{array}$ \\
\hline & & L4 & Product & $\begin{array}{l}\text { Rooikat Armoured Vehicle } \\
\text { Tank, etc }\end{array}$ & $\begin{array}{l}\text { Cell - Self-maintaining systems in the } \\
\text { midst of throughput self-reproduction }\end{array}$ \\
\hline & & L3 & $\begin{array}{l}\text { Product Sub- } \\
\text { Assembly }\end{array}$ & Engine & $\begin{array}{l}\text { Control } \\
\text { Cybernetics- Closed loop control } \\
\text { systems }\end{array}$ \\
\hline & & L2 & Component & Fuel tank & $\begin{array}{l}\text { Clockwork- simple dynamic systems } \\
\text { Predetermined, necessary motion (may } \\
\text { exhibit equilibrium) }\end{array}$ \\
\hline & & L1 & Raw Material & Steel, plastics etc & $\begin{array}{l}\text { Frameworks- Static structures, requirin } \\
\text { accuracy in their description }\end{array}$ \\
\hline
\end{tabular}

\section{Figure 2: The Systems Hierarchy}

Interoperability is viewed as an overarching concept in relation to the other three levels of standardisation. Thus it is placed separately and higher on the hierarchy. It is linked with the two overarching levels (levels 9 and 10) because, from the DOD point of view, it must strategise within the overarching framework of the higher order AU/ASF and RSA Government (Developmental Peacekeeping) strategy.

At levels 7 and 8, the RSA DOD combines units to form an operational capability, 
and that is linked to the ISO definition of compatibility - namely, that units shall function together within the operational environment [3]. However, linking levels 8 and 7 is difficult, as Boulding [9] states: "Because of the vital importance for the individual man of symbolic images and behaviour based on them it is not easy to separate clearly the level of the individual human organism (level 7) from the next level (8), that of social organisations".

In the South African National Defence Force (SANDF), the different infantry battalions (units), each with their own distinctive character and esprit de corps, are regarded as a core capability (level 6) that is capable of deploying within the operational environment, substituting for one another - which is similar to the definition of interchangeability: units can be swapped within the operational environment [3].

The absence of humans at levels 1 to 5 makes it possible to manufacture or develop products (equipment), doctrine, and procedures that are identical. According to ISO [3], commonality implies that units are identical within the operational environment. The key lies in the notion of being identical. To be identical means to be the same, indistinguishable, equal, matching, alike, one and the same, and impossible to tell apart. This can only be obtained if the object, whether a process or item, complies with the same specification. (Humans cannot be identical.)

The NATO definition also states that standardisation occurs in the operational, procedural, administrative, materiel, and technology fields. The execution of standardisation in the defined fields, expressed in terms of the levels of standardisation, implies that the fields are present at each system hierarchy level, as depicted in Figure 3.

The emphasis on designing objectives at the highest strategic level is primarily in the operational, procedural, and administrative fields; once consensus is reached, the means (materiel \& technology) of accomplishing standardisation is considered. Cascading the strategic requirement is the essence of this model. The low level translation of the need is converted into a physical item that best fulfils the need, which in turn 'creates' specific requirements that must be considered by the top level when applying the piece of equipment.

The relationships illustrated in Figure 3 partially answer the research objective we stated earlier. The concepts that could possibly be used to promote the understanding of interoperability and standardisation were identified and visualised. The next step is to explore the DOD management's knowledge base regarding the elements of the model.

A top-down (inputs), bottom-up (output) approach covering all the standardisation fields with different levels of standardisation is thus required [11], justifying the systems engineering process in the model, as shown in Figure 3. 


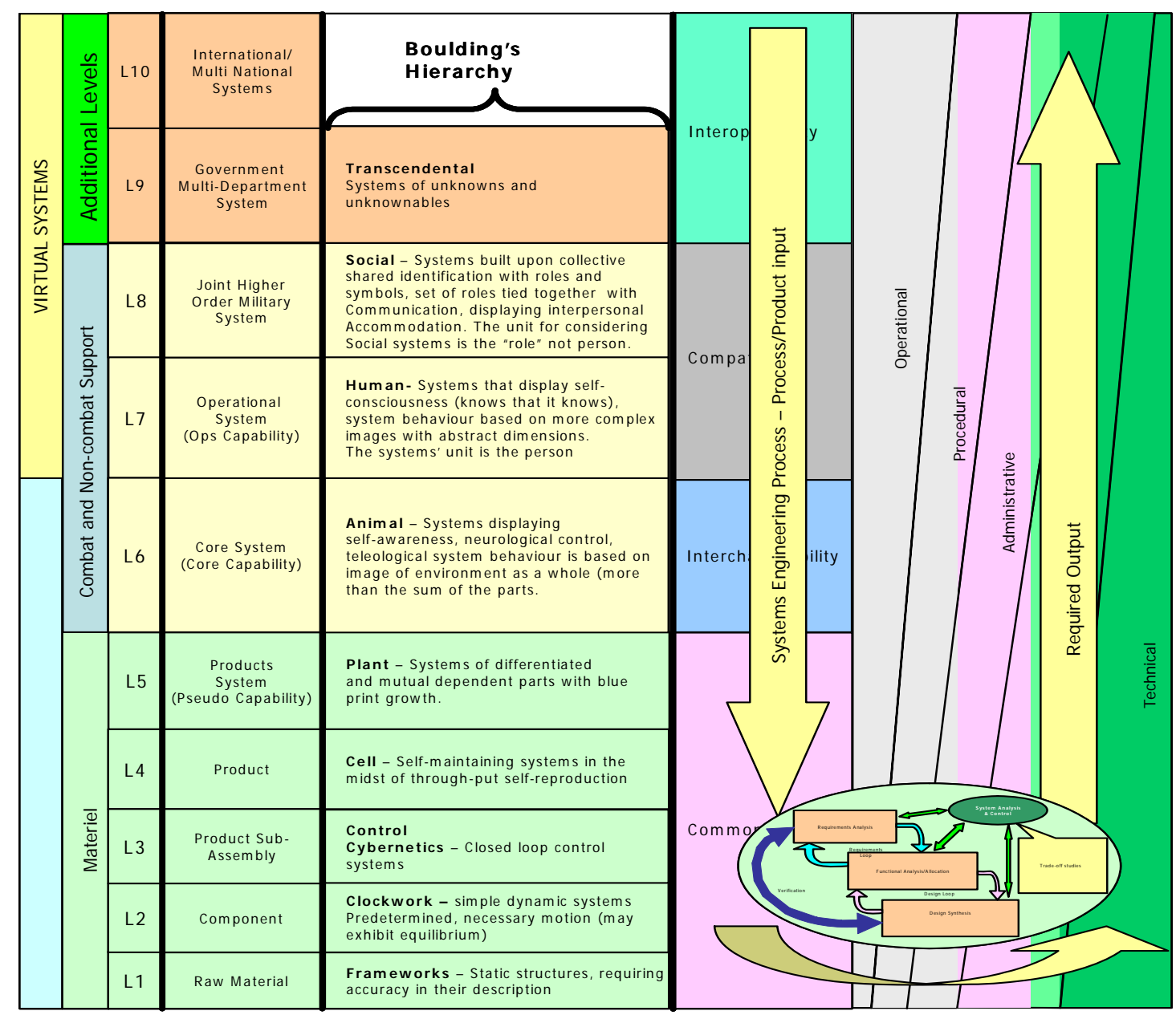

Figure 3: The Systems Hierarchy and the Systems Engineering Process

\section{UNDERSTANDING OF INTEROPERABILITY AND STANDARDISATION IN THE DOD}

The proposed model, being a full representation of a set of relationships, including statements about assumptions and interactions, was based on theories and common practices that were derived from secondary data. The justification of the concepts within the model is explored now by analysing new data obtained by means of structured interviews and observations. A questionnaire was the main instrument used. The questions were not open-ended, but designed to measure participants' agreement or disagreement with specific statements.

The population of interest were managers from the DOD and Armscor. A total of 175 participated. Of these, 36 were at top management level, 96 were middle managers, and 43 were at supervisory level.

The concepts 'interoperability', ‘compatibility', ‘interchangeability', and 'commonality', used by NATO in their standardisation definitions, were presented to determine whether the group could relate the four concepts to 'standardisation'. As shown in Figure 4, the group did relate the four concepts to standardisation. 
However, it is noteworthy that 'commonality', which is the highest level of standardisation, is the least related or recognised.

The level of understanding is measured by the group's ability to link the concepts precisely. Only 60\% could so link them, as reflected in Figure 5.

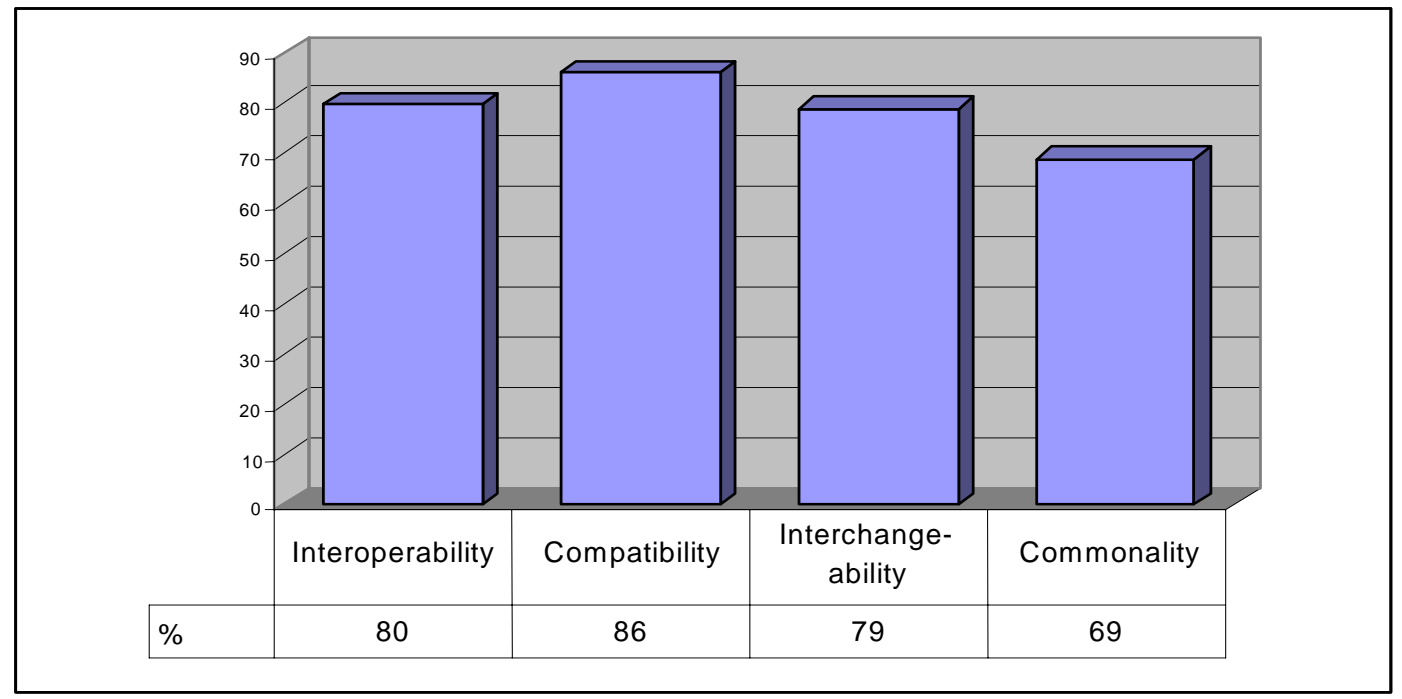

Figure 4: Concepts Related to Standardisation

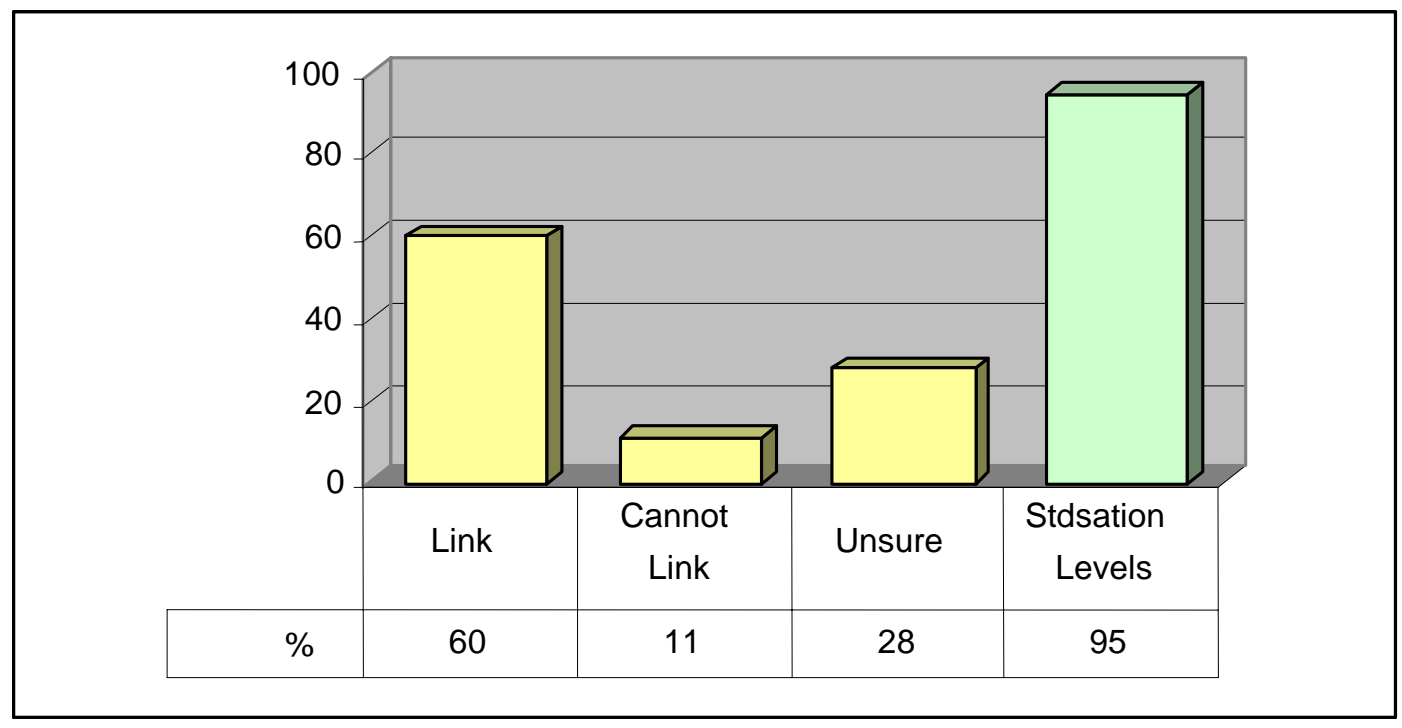

Figure 5: Linking the Concepts

Even though they could not precisely link the concepts, 95\% of the group were aware that there are levels of standardisation, as mentioned in the definition.

Assuming group consensus on the presence of standardisation in processes, it was necessary to determine the fields in which they expected standardisation to take place. The group indicated the fields in which they saw standardisation implemented. 
This result was verified by their reaction to the question whether standardisation was restricted to materiel/equipment only. Ninety-five percent of the respondents confirmed that standardisation encompassed more than the standardisation of materiel/equipment. The results are reflected in Figure 6.

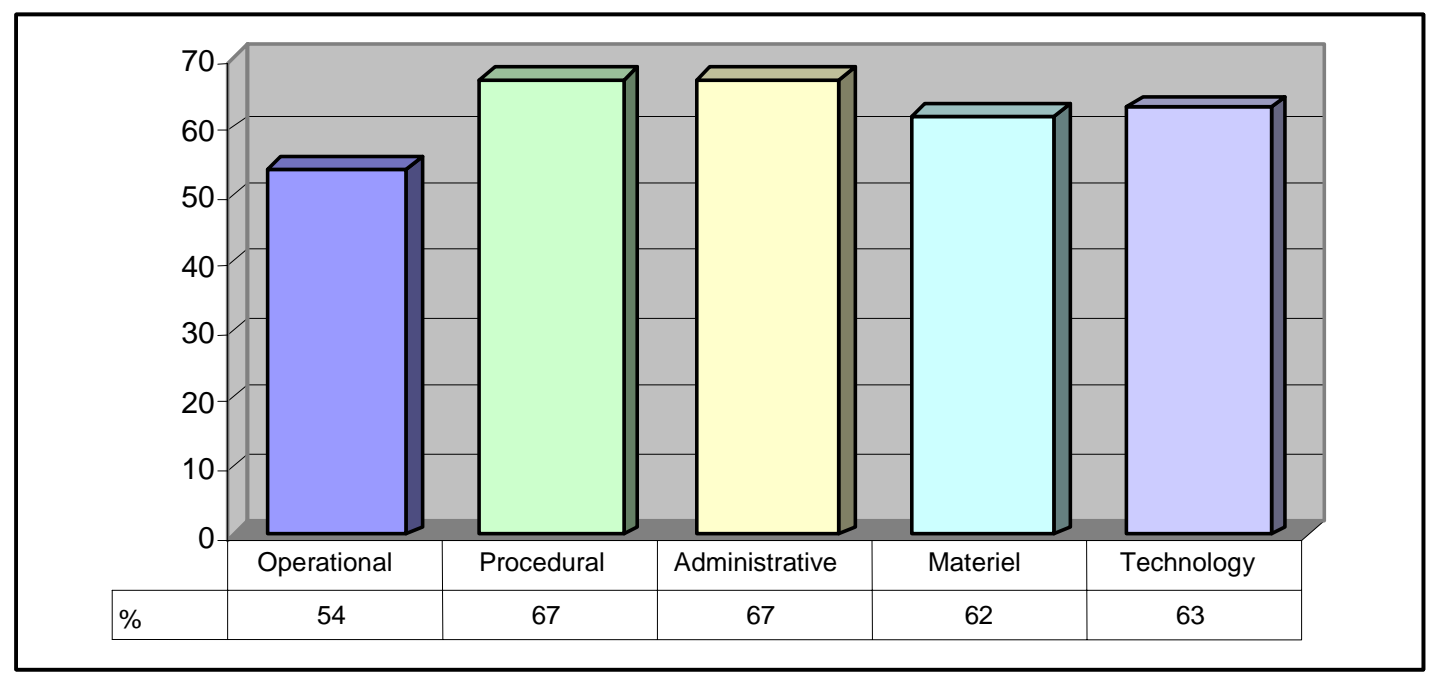

Figure 6: Knowledge of Systems

The group's familiarity with systems and the systems hierarchy was also tested. A high percentage indicated that they were familiar with systems (88\%) and the systems hierarchy (80\%), and that they could plot themselves on the systems hierarchy (75\%), as shown in Figure 7.

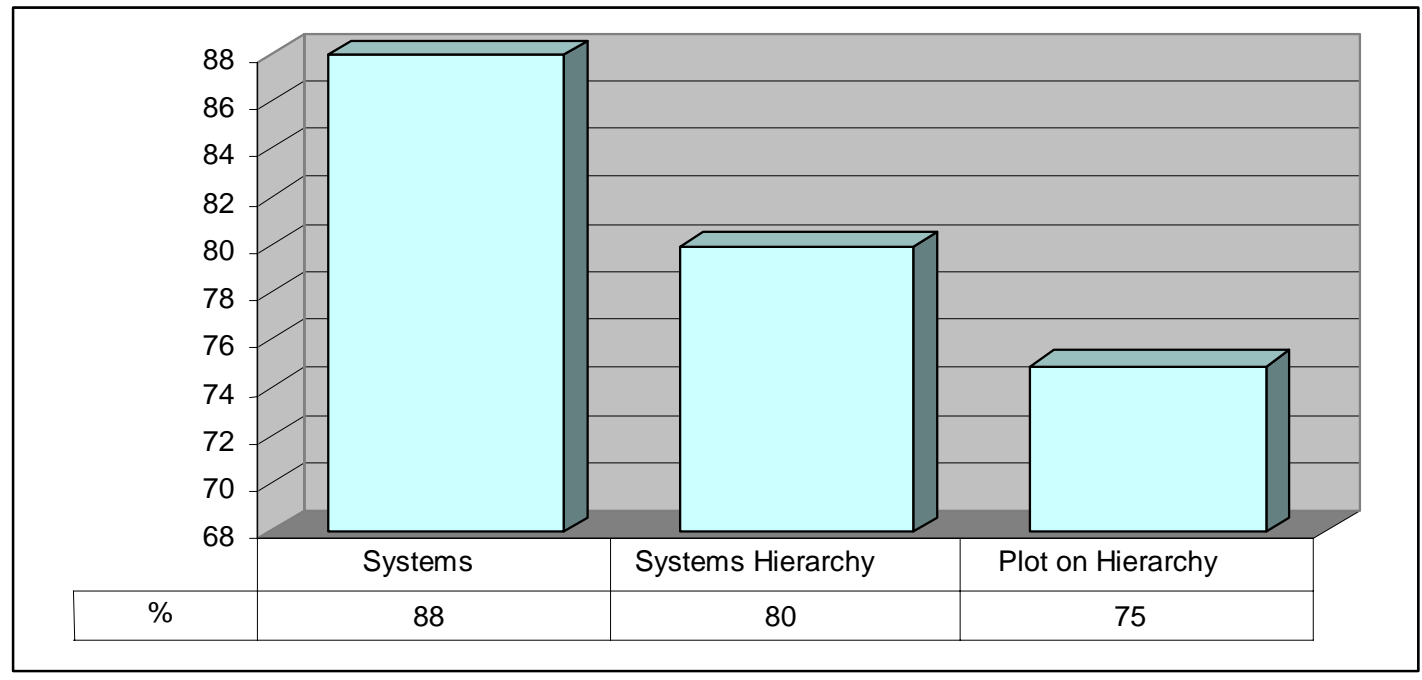

Figure 7: Respondents' Allocation of Standardisation to the Different Fields

The group were asked to say at which management level standardisation should be initiated. The majority (78\%) indicated that it had to start with top management, indicating that the top-down systems engineering process could be used. The systems engineering process is initiated with a requirement statement derived from a mission and environment analysis, with the aim of identifying functional requirements and 
defining performance and design requirements. These requirements must satisfy the organisational missions. The group was also tested in this regard, and $62 \%$ indicated that the DOD is mission-driven. This question elicited the comment from many participants that, although their organisations are mission-driven, they are budgetconstrained, thus shifting the focus from missions to budgets.

Seventy-eight percent of the sample group indicated that their knowledge concerning standardisation was not high but medium. However, 95\% had a strong desire to improve their knowledge. Different possible methodologies of knowledge transfer were suggested, and the group responded that they preferred workshops. Their response is reflected in Figure 8.

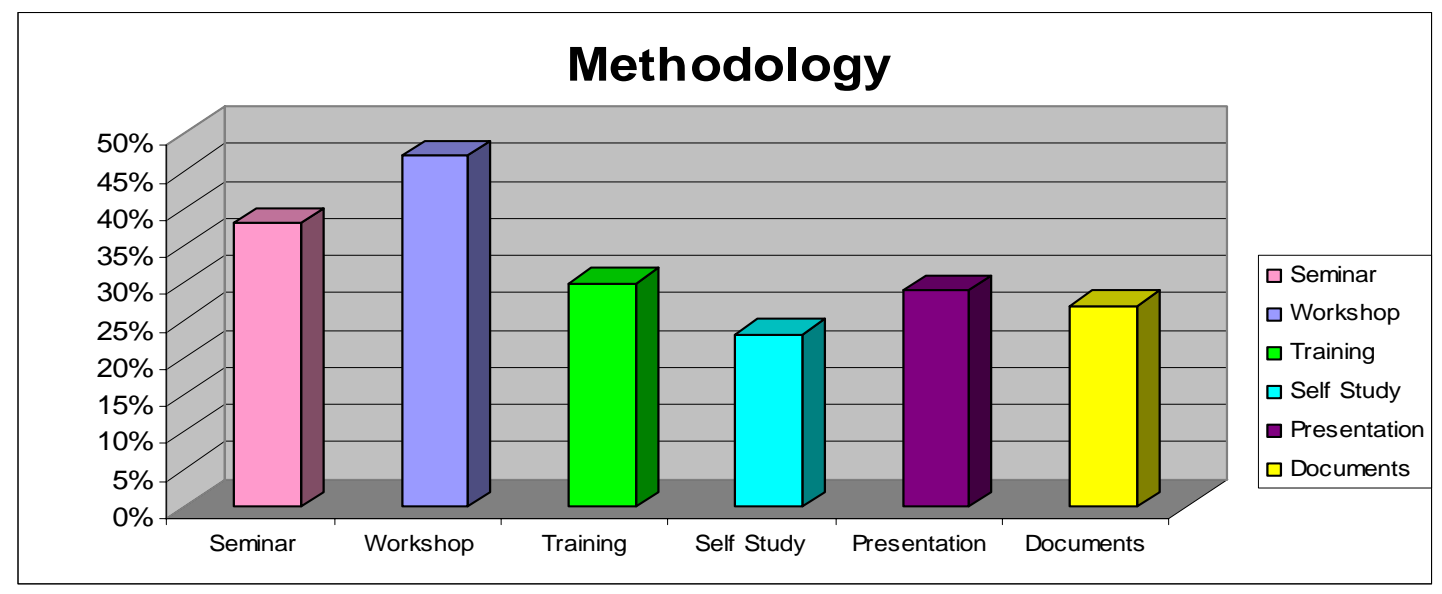

Figure 8: Methodology to Promote Standardisation

\section{CONCLUSIONS}

In the light of the problem statement and objectives of this study, it is clear from the data analysis that the following results have been achieved:

- The research determined and explored, to a certain extent, the DOD's knowledge pertaining to standardisation.

- The research questions determined the following:

- The managers from strategic to execution level did not have the same understanding of the concepts of standardisation and interoperability. The need to enlighten them therefore exists.

- They realised that standardisation formed an integral part of all systems, but were uncertain about the extent to which the proposed integrative model applied.

- They indicated that they were familiar with systems and systems hierarchies; however, they were uncertain about their positions in the systems hierarchy.

- They agreed that standardisation should be initiated at the top level of management, which means that the process of creating the same 
understanding of interoperability and standardisation should also start at top management level. This gives substance to the use of systems engineering principles.

- They were somewhat indifferent about how they wished to attain the required knowledge of standardisation, although most preferred a combination of workshops and seminars.

The contributions of the research are the following:

- $\quad$ The model can be used at any level of systems hierarchy, because it is applicable to every manager, no matter the hierarchical level at which he/she operates.

- $\quad$ People can place their respective functions on the systems hierarchy.

- $\quad$ They identify their field of activity and its interfaces with others.

- They apply the terminology/concepts to the immediate environment.

- They see the applicability of the top-down initiation / bottom-up reaction process.

- $\quad$ They realise that standardisation is designed into a system.

- They familiarise themselves with systems engineering, especially the recursive problem-solving process, and the necessity to integrate their activities more widely than their own function.

- They see the inter-dependability of each activity and the influence of a decision right through the system.

- $\quad$ They observe the important link between a mission and the resources required to achieve it, and they realise that materiel and technology are only tools or constraints of a mission.

- $\quad$ Every member has a major role to play in, and responsibility for, executing standardisation.

- All realise that standardisation is not a separate task but part and parcel of dayto-day management.

- $\quad$ All have the opportunity to enhance the understanding of systems and systems hierarchy, the systems thinking process, and through-life management in the DOD.

- All realise that at each level there is interoperability and standardisation of varied intensity - that at the highest systems hierarchy level there are certain things that have to be common, compatible, or interchangeable.

The model, with the elements combined in this configuration, is a valuable method of visualising the relationships of these concepts, and of achieving better understanding 
of them. The current knowledge base (definitions and concepts) and pictured relationships can create a generally accepted interpretation of interoperability, compatibility, interchangeability, and commonality (standardisation), and must thus be exploited.

Interoperability is by no means a purely military problem or concept. Any organisation, public or private, that wishes to buy out or cooperate with another organisation should be deeply interested in the interoperability of the two organisations' systems, and specifically their respective IT infrastructures and databases. This has become such a problem for the United States Government that a Congressional Act, the so-called Clinger-Cohen Act of 1996, specifies how interoperability is to be accomplished between government departments [12]. That approach is now mandatory for any system acquisition for the US Department of Defense.

In response to the Clinger-Cohen Act, the US Department of Defense has issued the so-called DOD Architecture Framework (DoDAF) [13]. The DoDAF provides direction for developing enterprise architectures for DOD war-fighting and business operations. The DoDAF is partitioned into three views of an enterprise's business and information technology structure: operational, systems, and technical standards. Other US government departments have similarly published their own architecture frameworks - for example, the Federal Enterprise Architecture and the Treasury Enterprise Architecture. These concepts have not been formally applied in South Africa, but they should be investigated with the aim of improving interoperability between organisations.

\section{REFERENCES}

[1] South Africa Department of Defence, 2003. Strategic Business Plan FY2003/04 to FY2005/06. Pretoria: Government Printer.

[2] NATO, 2001. NATO Handbook. NATO Office of Information and Press, Belgium.

[3] United Kingdom Def Stan, 2002. AMS Additional Information Addressing Standardization UK DStan Policy Division, Abbey Wood, Bristol.

[4] NATO, 2003. AAP-6 NATO Glossary of Terms and Definitions. NATO Office of Information and Press, Belgium.

[5] United Kingdom Ministry of Defence, 1999. Standards for Defence Part 1: MOD UK Standardization Policy, Organizations and Implementation. UK MOD.

[6] Codner, M. 2003. Hanging Together. Military Interoperability in an Era of Technological Innovation. The Royal United Services Institute for Defence Studies. Whitehall Paper 56. London.

[7] Bellinger, G. 2004. Systems Understanding - The Way. Retrieved from http://www.systems-thinking.org/systems/systems.htm. Visited 2 October 2004.

[8] Hodge, R. and Walpole, G., 1999. A Systems Approach to Defence Capability Planning - Work in Progress. SETE99 Paper 4, Department of Defence, Australia. 
[9] Boulding, K.E., 1956. General Systems Theory - The Skeleton of Science. Management Science. Vol. 2, No 3: 197-208.

[10] United Kingdom Def Stan, 2000. DSTAN Policy: Smart Standardisation UK DStan Policy Division, Abbey Wood, Bristol.

[11] United States of America Department of Defense, 2001. Systems Engineering Fundamentals. Defence Acquisition University Press, Fort Belvoir, Virginia, USA.

[12] Clinger-Cohen Act of 1996 (formerly the Information Technology Management Reform Act (ITMRA) of 1996), USA.

[13] DoD Architecture Framework Working Group, 2004. DoD Architecture Framework, version 1.0, 9 February 2004. 